\title{
Distinct morphological features of NADPH diaphorase neurons across rodent's primary cortices
}

\author{
Marco A. M. Freire ${ }^{1 *}$ and José R. Santos ${ }^{2}$ \\ 1 Laboratory of Cellular Neurobiology, Edmond and Lily Safra International Institute for Neuroscience of Natal, Natal, Brazil \\ 2 Department of Biology, Federal University of Sergipe, Aracaju, Brazil \\ ${ }^{*}$ Correspondence: freire.m@gmail.com \\ Edited by: \\ Bruno Cauli, Centre National de la Recherché Scientifique and Université Pierre et Marie Curie, France \\ Reviewed by: \\ Kathleen S. Rockland, Massachusetts Institute of Technology, USA
}

\section{A commentary on}

Distribution and morphology of nitrergic neurons across functional domains of the rat primary somatosensory cortex

by Nogueira-Campos, A. A., Finamore, D. M., Imbiriba, L. A., Houzel, J. C., and Franca, J. G. (2012). Front. Neural Circuits 6:57. doi: 10.3389/fncir.2012.00057

Nitric oxide (NO) is a versatile gaseous molecule involved in several pathological and physiological functions in nervous system (Calabrese et al., 2007; Steinert et al., 2010; Freire, 2012). Its biosynthesis occurs after the stoichiometric conversion of $\mathrm{L}$-arginine to $\mathrm{L}$-citrulline in a process requiring the presence of $\mathrm{NADPH}$ and $\mathrm{O}_{2}$ as co-substrates (Bredt and Snyder, 1994). A group of enzymes known as nitric oxide synthases (NOS) is responsible to synthesize NO (Stuehr et al., 2004). In the brain, neuronal NOS is strictly co-localized with NADPH diaphorase (NADPH-d), an oxidative enzyme present in a discrete population of interneurons (Dawson et al., 1991). NADPH-d histochemistry has been used to reveal the presence of NO dispersed in neuropil and to evaluate the presence and distribution of NO-synthesizing neurons across several species (Vincent et al., 1983; Sandell, 1986; Mizukawa et al., 1989; Yan et al., 1996; Franca et al., 2000; Freire et al., 2010, 2011).

Previous studies concerning NADPH$\mathrm{d} / \mathrm{NOS}$ reactive neurons focused mainly in its distribution around brain. Differences in morphology were described qualitatively. More recently, a growing amount of information regarding differences in morphometric parameters of this cell group, based in neuronal reconstructions, has emerged (Freire et al., 2007, 2012; Rocha et al., 2012). In light of this, an interesting question arises: could morphological differences of nitrergic neurons among distinct cortical areas or throughout subdivisions of a given area in rodents be associated to their distinct physiologies, as observed to pyramidal neurons (Elston et al., 2006)?

In rodents, primary somatosensory cortex (S1) is a suitable area to be explored since the complete body's representation delineates a topologically correlated cortical map (Rocha et al., 2007; Santiago et al., 2007) commonly revealed by NADPH-d histochemistry (Freire et al., 2012). The general pattern of NADPHd-reactive neuropil is markedly similar to observed with cytochrome oxidase histochemistry, since both are oxidative enzymes involved in the energetic metabolism (Wong-Riley et al., 1998). The main representation of $S 1$ in rats and mice corresponds to the posterior medial barrel subfield (PMBSF), the region where mystacial vibrissae are represented and the largest and more defined barrels are found. Previous studies have shown that, in a tangential view, NADPH-d neurons concentrate along the regions of PMBSF that separate barrels from each other, known as septa (Franca and Volchan, 1995; Freire et al., 2004). Nevertheless, other S1 regions were not explored in these studies.

In this context, a comprehensive work published by Nogueira-Campos et al. (2012) in Frontiers in Neural Circuits contributes to cover this gap. In that study the authors evaluated the entire population of NADPH-d neurons found across rat's $\mathrm{S} 1$ in order to quantify the distribution of these cells throughout all body's representation and also evaluate the morphological aspects and relationship of these neurons with barrels and septal regions. Similar to previously described to PMBSF (Franca and Volchan, 1995; Freire et al., 2004), NADPH-d neurons were not limited by compartment borders across $\mathrm{S} 1$. Besides, cell density in septal regions was higher than inside barrels. Regarding morphometric measurements, only in one case evaluated by the authors there was an evident difference between neurons found in septa and barrels, as previously reported (Franca and Volchan, 1995; Freire et al., 2004), what can be explained by the plan of section adopted (coronal $v s$. tangential). But what might these morphological differences represent, in terms of physiology, along distinct regions across rodent's S1? Septal and barrel regions are physiologically/functionally distinct (Alloway, 2008) since septal neurons display significant differences in response latencies related to variations in the frequency of whisker stimulation when compared to barrel neurons (Chakrabarti and Alloway, 2009). In addition both regions receive projections from separated thalamic nuclei (Killackey and Sherman, 2003). Accordingly, barrels and septa would require a segregated circuitry in these different zones, what may be correlated to morphometric differences observed in NADPH-d neurons in both regions. These structural differences could reflect specializations in the processing of sensory information across distinct cortical areas, meaning a difference in their capacity for synaptic integration because dendritic coverage is directly related to the amount of synaptic contacts a cell may receive. Accordingly, neurons possessing a smaller dendritic arbor cover a small cortical area and potentially establish fewer synaptic contacts 
than more ramified cells. Because septal region is thought to be a segregated cortex from barrels (Killackey and Sherman, 2003), both regions represent two different processing streams that analyze distinct information (Alloway, 2008). So, more complex interneurons in septa could integrate a broader range of synaptic inputs than those found inside barrels.

In conclusion, data provided by Nogueira-Campos et al. (2012) offer new insights about the organization of interneuron circuitry across rat's S1. A further quantification of NADPH-d neuronal morphology in non-primary/association areas may contribute to a more complete notion of cortical differences in the inhibitory circuitry.

\section{ACKNOWLEDGMENTS}

The authors would like to thank Associação Alberto Santos Dumont para Apoio à Pesquisa (AASDAP)—Brazil for the logistical support.

\section{REFERENCES}

Alloway, K. D. (2008). Information processing streams in rodent barrel cortex: the differential functions of barrel and septal circuits. Cereb. Cortex 18, 979-989.

Bredt, D. S., and Snyder, S. H. (1994). Nitric oxide: a physiologic messenger molecule. Annu. Rev. Biochem. 63, 175-195.

Calabrese, V., Mancuso, C., Calvani, M., Rizzarelli, E., Butterfield, D. A., and Stella, A. M. (2007). Nitric oxide in the central nervous system: neuroprotection versus neurotoxicity. Nat. Rev. Neurosci. 8, 766-775.

Chakrabarti, S., and Alloway, K. D. (2009). Differential response patterns in the si barrel and septal compartments during mechanical whisker stimulation. J. Neurophysiol. 102, 1632-1646.

Dawson, T. M., Bredt, D. S., Fotuhi, M., Hwang, P. M., and Snyder, S. H. (1991). Nitric oxide synthase and neuronal NADPH diaphorase are identical in brain and peripheral tissues. Proc. Natl. Acad. Sci. U.S.A. 88, 7797-7801.

Elston, G. N., Elston, A., Freire, M. A. M., Gomes-Leal, W., Pereira, A. Jr., Silveira, L. C. L., et al. (2006). Specialization of pyramidal cell structure in the visual areas V1, V2 and V3 of the South American rodent, Dasyprocta primnolopha. Brain Res. 1106 , 99-110.

Franca, J. G., and Volchan, E. (1995). NADPH diaphorase histochemistry as a marker for barrels in rat somatosensory cortex. Braz. J. Med. Biol. Res. 28, 787-790.

Franca, J. G., Volchan, E., Jain, N., Catania, K. C., Oliveira, R. L., Hess, F. F., et al. (2000). Distribution of NADPH-diaphorase cells in visual and somatosensory cortex in four mammalian species. Brain Res. 864, 163-175.

Freire, M. A. M. (2012). Pathophysiology of neurodegeneration following traumatic brain injury. West Indian Med. J. 61, 751-755.

Freire, M. A. M., Faber, J., Picanço-Diniz, C. W., Franca, J. G., and Pereira, A. (2012). Morphometric variability of nicotinamide adenine dinucleotide phosphate diaphorase neurons in the primary sensory areas of the rat. Neuroscience 205 140-153.

Freire, M. A. M., Gomes-Leal, W., Carvalho, W. A., Guimaraes, J. S., Franca, J. G., Picanço-Diniz, C. W., et al. (2004). A morphometric study of the progressive changes on NADPH diaphorase activity in the developing rat's barrel field. Neurosci. Res. 50, 55-66.

Freire, M. A. M., Morya, E., Faber, J., Santos, J. R., Guimaraes, J. S., Lemos, N. A. M., et al. (2011). Comprehensive analysis of tissue preservation and recording quality from chronic multielectrode implants. PLOS ONE 6:e27554. doi: 10.1371/journal.pone.0027554

Freire, M. A. M., Oliveira, R. B., Picanço-Diniz, C. W., and Pereira, A. Jr. (2007). Differential effects of methylmercury intoxication in the rat's barrel field as evidenced by NADPH diaphorase histochemistry. Neurotoxicology 28, 175-181.

Freire, M. A. M., Rocha, E. G., Oliveira, J. L. F., Guimaraes, J. S., Silveira, L. C. L., Elston, G. N., et al. (2010). Morphological variability of NADPH diaphorase neurons across areas $\mathrm{V} 1, \mathrm{~V} 2$, and V3 of the common agouti. Brain Res. 1318C, 52-63.

Killackey, H. P., and Sherman, S. M. (2003). Corticothalamic projections from the rat primary somatosensory cortex. J. Neurosci. 23, 7381-7384.

Mizukawa, K., Vincent, S. R., McGeer, P. L., and McGeer, E. G. (1989). Distribution of reducednicotinamide-adenine-dinucleotide-phosphate diaphorase-positive cells and fibers in the cat central nervous system. J. Comp. Neurol. 279, 281-311.

Nogueira-Campos, A. A., Finamore, D. M., Imbiriba, L. A., Houzel, J. C., and Franca, J. G. (2012). Distribution and morphology of nitrergic neurons across functional domains of the rat primary somatosensory cortex. Front. Neural Circuits 6:57. doi: 10.3389/fncir.2012.00057
Rocha, E. G., Freire, M. A. M., Bahia, C. P., Pereira, A., Sosthenes, M. C., Silveira, L. C., et al. (2012). Dendritic structure varies as a function of eccentricity in V1: A quantitative study of NADPH diaphorase neurons in the diurnal South American rodent agouti, Dasyprocta prymnolopha. Neuroscience 216, 94-102.

Rocha, E. G., Santiago, L. F., Freire, M. A. M., GomesLeal, W., Lent, R., Houzel, J. C., et al. (2007). Callosal axon arbors in the limb representations of the somatosensory cortex (SI) in the agouti (Dasyprocta primnolopha). J. Comp. Neurol. 500, 255-266.

Sandell, J. H. (1986). NADPH diaphorase histochemistry in the macaque striate cortex. J. Comp. Neurol. 251, 388-397.

Santiago, L. F., Rocha, E. G., Freire, M. A. M., Lent, R., Houzel, J. C., Picanço-Diniz, C. W., et al. (2007). The organizational variability of the rodent somatosensory cortex. Rev. Neurosci. 18, 283-294.

Steinert, J. R., Chernova, T., and Forsythe, I. D. (2010). Nitric oxide signaling in brain function, dysfunction, and dementia. Neuroscientist 16, 435-452.

Stuehr, D. J., Santolini, J., Wang, Z. Q., Wei, C. C. and Adak, S. (2004). Update on mechanism and catalytic regulation in the NO synthases. J. Biol. Chem. 279, 36167-36170.

Vincent, S. R., Johansson, O., Hokfelt, T., Skirboll, L., Elde, R. P., Terenius, L., et al. (1983). NADPHdiaphorase: a selective histochemical marker for striatal neurons containing both somatostatinand avian pancreatic polypeptide (APP)-like immunoreactivities. J. Comp. Neurol. 217, 252-263.

Wong-Riley, M., Anderson, B., Liebl, W., and Huang, Z. (1998). Neurochemical organization of the macaque striate cortex: correlation of cytochrome oxidase with $\mathrm{Na}+\mathrm{K}+$ ATPase, NADPH-diaphorase, nitric oxide synthase, and $\mathrm{N}$-methyl-D-aspartate receptor subunit 1. Neuroscience 83, 1025-1045.

Yan, X. X., Jen, L. S., and Garey, L. J. (1996). NADPHdiaphorase-positive neurons in primate cerebral cortex colocalize with GABA and calcium-binding proteins. Cereb. Cortex 6, 524-529.

Received: 01 April 2013; accepted: 12 April 2013; published online: 26 April 2013.

Citation: Freire MAM and Santos JR (2013) Distinct morphological features of NADPH diaphorase neurons across rodent's primary cortices. Front. Neural Circuits 7:83. doi: 10.3389/fncir.2013.00083

Copyright (c) 2013 Freire and Santos. This is an openaccess article distributed under the terms of the Creative Commons Attribution License, which permits use, distribution and reproduction in other forums, provided the original authors and source are credited and subject to any copyright notices concerning any third-party graphics etc. 